\title{
DINAMIKA PERAN PEREMPUAN DALAM PENGEMBANGAN PARRIWISATA DI DAERAH PESISIR KABUPATEN REMBANG (Studi Deskriptif Obyek Wisata Pantai Karang Jahe Desa Punjulharjo Kecamatan Rembang, Kabupaten Rembang)
}

\author{
Rizka Adhe Yuanita ${ }^{1}$, Drs. Thomas Aquinas Gutama, $\mathbf{M} \mathrm{Si}^{2}$ \\ Program Studi Sosiologi Fakultas Ilmu Sosial dan Politik \\ Universitas Sebelas Maret Surakarta Indonesia \\ Email: rizkaadheyuanita@gmail.com
}

\begin{abstract}
This study aims to determine the role of women in the development of tourism in the coastal area of Rembang Regency and to determine the factors that influence the role of women in the development of tourism in the coastal area of Rembang Regency. This study uses qualitative research methods with a descriptive approach. The results showed that the role of women in the development of tourism in the coastal area of Karang Jahe Beach, Punjulharjo Village, Rembang Regency was very instrumental in the attraction and provision of facilities in the Karang Jahe Beach tourist area. This is evidenced by the involvement of the role of women in training activities conducted by relevant parties and providing tourism facilities by opening business activities such as trading in tourist areas to provide visitors' needs. However, in accessibility and tourism organizations, the role of women is felt to be lacking because only a few are involved. Factors influencing the role of women in the development of Karang Jahe tourism include: lack of coordination, lack of knowledge and skills, still adhering to a patriarchal system and the existence of ancestral culture.
\end{abstract}

Keywords: tourism, women's role, coastal.

Abstrak: Penelitian ini bertujuan untuk mengetahui peran perempuan dalam pengembangan pariwisata di daerah pesisir Kabupaten Rembang dan untuk mengetahui faktor-faktor yang mempengaruhi peran perempuan dalam pengembangan pariwisata di daerah pesisir Kabupaten Rembang. Penelitian ini menggunakan metode penelitian kualitatif dengan pendekatan deskriptif. Hasil penelitian menunjukkan bahwa peran perempuan dalam pengembangan pariwisata di daerah pesisir Pantai Karang Jahe Desa Punjulharjo Kabupaten Rembang sangat berperan dalam atraksi dan penyediaan fasilitas di kawasan wisata Pantai Karang Jahe. Hal tersebut dibuktikan dari keterlibatan peran perempuan dalam kegiatan pelatihan-pelatihan yang diadakan oleh pihak-pihak terkait dan menyediaakan fasilitas wisata dengan membuka kegiatan usaha seperti berdagang di kawasan wisata untuk menyediakan kebutuhan-kebutuhan pengunjung. Akan tetapi dalam aksesbilitasi dan tourism organization, peran perempuan dirasa masih kurang karena hanya sedikit yang terlibat. Faktor yang mempengaruhi peran perempuan dalam pengembangan pariwisata Pantai Karang Jahe ini berupa : kurangnya koordinasi, kurangnya pengetahuan dan ketrampilan, masih menganut sistem patriarki dan masih adanya budaya nenek moyang yang dianut. 
Kata kunci: pariwisata, peran perempuan, pesisir.

\section{PENDAHULUAN}

Pariwisata merupakan salah satu andalan Indonesia sebagai penghasil devisa, kerja sama di forum internasional dan regional seperti UNWTO (United Nations World Tourism Organization) dan Pacific Asia Travel Assiociation (PATA) sangatlah penting, terutama untuk menjalin kerja sama pelatihan, penanaman modal, dan tukar-menukar pengalaman. UNWTO memiliki Business Council yang beranggotakan badan-badan pariwisata nonpemerintah. Saat ini, UNWTO sedang mempromosikan ekoturisme sebagai salah satu obyek penarik wisatawan, sekaligus sebagai program untuk melestarikan alam. Rangkaian kegiatan yang dilakukan termasuk seminar, lokakarya, dan publikasi. Mengingat Indonesia memiliki banyak obyek wisata alam, ekoturisme dapat menjadi salah satu bidang kerja sama dengan UNWTO. UNWTO juga memfokuskan diri pada pemanfaatan situs-situs budaya untuk mendukung pariwisata. Untuk itu UNWTO melakukan serangkaian kegiatan seperti penelitian di situs-situs budaya, seminar dan publikasi untuk mempromosikan situs budaya, serta penelitian lapangan untuk membantu pemerintah setempat memanfaatkan situs budayanya (Kemenlu, 2019).

Undang-Undang Nomor 10 Tahun 2009 tentang Kepariwisataan menyebutkan bahwa pariwisata adalah berbagai macam kegiatan wisata yang didukung berbagai fasilitas serta yang disediakan oleh masyarakat, pengusaha, pemerintah, dan pemerintah daerah. Selain itu berbagai sektor yang kompleks dan meliputi industri-industri kerajinan dan cindera mata, penginapan, dan transportasi secara ekonomis juga dipandang sebagai industri. Pasal tersebut juga menyebutkan 10 tujuan penyelenggaraan kepariwisataan Indonesia yaitu: (1) meningkatkan pertumbuhan ekonomi, (2) meningkatkan kesejahteraan rakyat, (3) menghapus kemiskinan, (4) mengatasi pengangguran, (5) melestarikan alam, (6) lingkungan, dan sumber daya, (6) menunjukan kebudayaan, (7) mengangkat citra bangsa, (8) memupuk rasa cinta tanah air, (9) memperkukuh jati diri dan kesatuan bangsa, serta (10) mempererat persahabatan antar bangsa.

Daerah pesisir dan lautan Indonesia yang kaya dan beragam sumber daya alamnya telah dimanfaatkan oleh bangsa Indonesia sebagai salah satu sumber bahan makan utama, khususnya protein hewani. Selain menyediakan berbagai sumber daya tersebut, wilayah pesisir Indonesia memiliki berbagai fungsi lain, seperti transportasi dan pelabuhan, kawasan industri, agribisnis dan agroindustri, rekreasi dan pariwisata, serta kawasan pemukiman dan tempat pembuangan limbah (Haryono dan Nugraheni, 2018).

Kabupaten Rembang merupakan salah satu kota/kabupaten yang berada di sebelah utara Pulau Jawa, tepatnya di Provinsi Jawa Tengah. Pemerintah Kabupaten Rembang saat ini sedang berusaha untuk mengembangkan pariwisata dengan memunculkan potensipotensi daerah yang mampu dijadikan sebagai objek wisata terutama di daerah pesisir utara Rembang melalui program-program yang sudah dirancang guna untuk menambah daya tarik wisatawan untuk berkunjung ke Rembang, karena Rembang berada di sebelah utara Pulau Jawa dimana yang berbatasan langsung dengan dengan laut utara dan memiliki garis pantai yang panjang di Jawa Tengah sekitar $60 \mathrm{~km}$ dari Kecamatan Kaliori sampai dengan Kecamatan Sarang, sehingga terdapat banyak pantai-pantai yang berpotensi untuk dijadikan objek wisata. Wilayah Kabupaten Rembang punya banyak destinasi wisata baik wana wisata (wisata hutan), wisata pantai dan tempat bersejarah. Karena kabupaten Rembang, secara geografis terdiri dari daerah pesisir dan pegunungan. Sektor pariwisata di Kabupaten Rembang mengalami perkembangan yang cukup menggembirakan ditandai dengan meningkatnya kunjungan wisata. "Hingga bulan Desember 2018 wisatawan Nusantara sebanyak 1,8 juta lebih wisatawan dan Wisatawan Mancanegara sebanyak 556 wisatawan. 
Bahkan jumlah kunjungan wisatawan di Pantai Karang Jahe masuk ke dalam jajaran 7 Besar di Jajaran Jumlah kunjungan wisatawan Se-Jawa Tengah dengan capaian jumlah pengunjung 686.817 wisatawan," ungkap Bupati Rembang (Redaksi, 2019).

Dalam hal ini peran dan partisipasi dari masyarakat lokal menjadi sangat penting sebagai pelaku pariwisata dalam membantu mengembangkan pariwisata, mulai dari kalangan atas, menengah, bawah, baik kalangan pemerintah maupun swasta, bahkan lakilaki sampai perempuan ikut terlibat dalam pengembangan pariwisata. Peran dan partisipasi masyarakat dalam pengembangan pariwisata di Pantai Karang Jahe, Desa Punjulharjo ini dapat berupa atraksi, yaitu seperti kegiatan bersih-bersih pantai dan pengelolaan pantai atau akomodasi bisa dalam bentuk menjual makanan khas, oleh-oleh, cendera mata, atau penginapan, bahkan promosi untuk memperkenalkan obyek wisata Pantai Karang Jahe kepada masyarakat. Melalui peran dan partisipasi masyarakat lokal secara langsung ini diharapkan dapat menambah pendapatan dan meningkatkan kesejahteraan masyarakat terutama disekitar objek wisata.

Peran perempuan bagi pengembangan pariwisata sendiri merupakan salah satu unsur yang cukup penting dalam sebuah kegiatan pariwisata. Selama ini, peran perempuan selalu dipandang sebelah mata. Namun ke ikut sertaannya dalam sektor pariwisata akan mengurangi adanya ketimpangan gender dalam pembangunan pariwisata. Dalam pengembangan pariwisata Pantai Karang Jahe sendiri keterlibatan perempuan sangat berpengaruh untuk membantu mengembangkan pariwisata. Pengelola dari obyek wisata Pantai Karang Jahe sendiri sudah melibatkan peran perempuan baik dalam kepengurusan maupun di lapangan. Dengan demikian, apabila sektor pariwisata meningkat, pendapat daerah juga meningkat dan secara tidak langsung dana pembangunan juga akan meningkat. Oleh sebab itu, keterlibatan perempuan dalam sektor pariwisata perlu dipertimbangkan dan diperlihatkan agar perannya dalam pembangunan meningkat dan terciptanya kesetaraan gender.

Penelitian akan dianalisis menggunakan Teori Fungsionalisme Struktural Talcott Parsons mengenai konsep AGIL yaitu Adaptation, Goal attainment, Integrations, dan Latency. Adaptasi (adaptasi), sistem harus mengatasi kebutuhan situasional yang datang dari luar. Ia harus beradaptasi dengan lingkungan dan menyesuaikan lingkungan dengan kebutuhan-kebutuhannya. Goal attainment (pencapaian tujuan), sistem harus mendefinisikan dan mencapai tujuan-tujuan utamanya. Integration (integrasi), sistem harus mengatur hubungan bagian-bagian yang menjadi komponennya dan Latency (pemeliharaan pola), dimana sistem harus melengkapi, memelihara dan memperbaharui motivasi individu dan pola-pola budaya yang menciptakan dan mempertahankan motivasi tersebut (Ritzer dan Goodman, 2010 : 121).

\section{METODE PENELITIAN}

Penelitian dilakukan di Daerah Pesisir Pantai Karang Jahe Desa Punjulharjo, Kecamatan Rembang, Kabupaten Rembang. Penelitian ini menggunakan metode kualitatif dengan pendekatan deskriptif. Metode penelitian ini menggunakan kualitatif guna untuk mengetahui kondisi yang sebenarnya mengenai peran perempuan dalam pengembangan pariwisata di Obyek Wisata Pantai Karang Jahe Desa Punjulharjo. Penelitian ini menggunakan pendekatan deskriptif dimana peneliti akan mendapatkan data yang dapat dideskripsikan dengan jelas sehingga hasil penelitian ini benar-benar sesuai dengan kondisi lapangan yang ada.

Pemilihan informan dalam penelitian ini menggunakan teknik purposive sampling, dengan tujuan agar dapat diperoleh sampel yang memenuhi kriteria. Sugiyono (2008) menjelaskan bahwa Purposive sampling yaitu sampel yang ditarik dengan pertimbangan- 
pertimbangan tertentu sesuai dengan tujuan dan maksud penelitian. Individu-individu yang dipilih adalah individu yang dianggap cukup mengetahui permasalahan yang hendak diteliti serta memenuhi kriteria yang telah ditetapkan oleh peneliti. Teknik pengambilan data menggunakan data primer yakni berupa wawancara langsung dan data sekunder diperoleh dari dokumen dan foto. Teknik pengumpulan data menggunakan observasi, wawancara, hingga dokumentasi. Validitas data dalam penelitian menggunakan triangulasi data dengan membandingkan satu sumber dengan sumber lain yang berbeda.

\section{HASIL DAN PEMBAHASAN}

1. Peran Perempuan Dalam Pengembangan Pariwisata di Daerah Pesisir Kabupaten Rembang

Pengembangan pariwisata merupakan sebuah usaha/tindakan yang dilakukan oleh pemerintah maupun swasta dalam meningkatkan dan memaksimalkan potensi dalam bidang pariwisata yang ada di Indonesia untuk membantu menambah pendapatan negara dan dijadikan sebagai aset yang berharga bagi negara. Pengembangan sendiri dapat berupa pembangunan sesuatu hal untuk menjadi lebih baik di masa yang akan datang. Salah satu unsur pembangunan sendiri adalah masyarakat. Pengembangan atau pembangunan tempat wisata tidak lepas dari turut serta pasrtisipasi masyarakat sekitar. Dalam pengembangan pariwisata, partisipasi masyarakat lokal tidak bisa diabaikan. Masyarakat lokal lebih tahu tentang daerahnya daripada orang dari luar, karena itu keterlibatan masyarakat setempat dalam perencanaan, pelaksanaan dan pemanfaatan pembangunan obyek wisata sangat diperlukan. Dalam tahap perencanaan diperlukan keterlibatan masyarakat yang lebih besar, karena dalam tahap ini masyarakat diajak untuk membuat suatu keputusan. Hal ini dimaksudkan agar masyarakat mempunyai rasa memiliki sehinggga timbul kesadaran dan tanggung jawab untuk turut mengembangkannya.

Peran perempuan dalam Pengembangan Wisata Pantai Karang Jahe dapat dilihat dari aktivitas-aktivitas mereka dalam menunjang pariwisata. Peran Perempuan Desa Punjulharjo dalam pengambangan wisata Pantai Karang Jahe dapat dilihat dan dipahami dari berbagai pernyataan dan pengakuan perempuan setempat tentang keikutsertaan mereka dalam pengembangan pariwisata.

a. Peran Perempuan dalam Perencanaan

Dalam perencanaan pembangunan wisata Pantai Karang Jahe masih belum ada keterlibatan dari peran perempuan. Namun, keterlibatan dalam perencanaan tidak hanya dari aspek pembangunan, tetapi bisa juga dari aspek pengembangan pariwisata. Peran perempuan dalam perencanaan pengembangan wisata Pantai Karang Jahe dapat dilihat dan dipahami dari berbagai pernyataan dan pengakuan warga masyarakat setempat tentang keikutsertaan mereka dalam perencanaan pengembangan wisata Pantai Karang Jahe. Ada beberapa kelompok seperti kelompok pedagang yang seluruh anggotanya perempuan, biasanya mengadakan rapat rutin sebulan sekali dan pada mengadakan kegiatan kebersihan setiap hari jumat. Selain itu ada kelompok homestay yang terdiri dari ibu-ibu pemilik homestay. Namun untuk kelompok homestay ini diketahui sedang tidak aktif dikarenakan kurangnya informasi mengenai pengelolaan homestay.

Peran perempuan dalam perencanaan pengembangan pariwisata diwujudkan dengan keikutsertaanya dalam berbagai pelatihan dan tergabungnya ke dalam kelompok-kelompok pendukung wisata dengan 
keyakinan bahwa daerahnya memiliki keindahan alam dan potensi dari keberadaan Pantai Karang Jahe di daerah mereka. Selain itu juga diharapkan akan memberikan pengaruh sosial ekonomi dalam meningkatkan kesejahteraan masyarakat di Desa Punjulharjo. Menjadi anggota dan terlibat dalam kegiatan diskusi kelompok artinya ada suatu peran yang di berikan oleh perempuan.

b. Peran Perempuan dalam Pelaksanaan

Partisipasi Perempuan dalam Pelaksanaan Pengembangan Wisata Pantai Karang Jahe diwujudkan dengan keterlibatannya dalam mengelola wisata Pantai Karang Jahe dan mengikuti kegiatan-kegiatan pelatihan yang diadakan oleh pengelola Pantai Karang Jahe, pemerintah desa, maupun dari lembagalembaga pemerintah daerah. Dengan diadakannya pelatihan-pelatihan tersebut, diharapkan masyarakat Desa Punjulharjo khususnya bagi perempuan dapat memaksimalkan sumber daya dan potensi desa.

c. Peran Perempuan dalam Pemanfaatan

Manfaat yang ditimbulkan dari adanya Pantai Karang Jahe adalah bisa memberikan lapangan pekerjaan bagi ibu-ibu untuk membantu menambah penghasilan keluarga. Selain itu melalui pelatihan-pelatihan juga membantu menambah wawasan mengenai pengolahan-pengolahan potensi-potensi yang dimiliki desa dan sosialisasi-sosialisasi kepariwisataan yang belum mereka ketahui sebelumnya. Dari berbagai partisipasi yang di lakukan oleh perempuan-perempun desa wisata samiran ada manfaat manfaat yang di dapatkan dari partisipasi tersebut. Diantara manfaatnya adalah meningkatkan perekonomian, menambah pengalaman dengan mengikuti berbagai pelatihan, dan dapat mempromosikan usaha yang dimiliki.

2. Peran Perempuan dalam Komponen-Komponen Pariwisata Pengembangan Wisata Pantai Karang Jahe

a. Peran Perempuan dalam Atraksi

Dalam komponen ini dapat berupa kontribusinya dalam mengembangkan obyek wisata seperti kegiatan sapta pesona wisata di daerah pesisir dengan ikut andil dalam kegiatan bersih pantai, pelatihan penggunaan daur ulang sampah pantai, dan kegiatan lain yang dapat menunjang pengembangan pariwisata. peran perempuan dalam atraksi ini dapat berupa kegiatan-kegiatan yang dapat membantuk pengembangan pariwisata khususnya wisata Pantai Karang Jahe, seperti kegiatan bersih pantai, pelatihan pengolahan hasil laut, pelatihan kerajinan tangan, kerja bakti, sosialisasi pariwisata, dan lain-lain.

b. Peran Perempuan dalam Fasilitas

Dalam hal ini peran perempuan dapat terlibat sebagai penjual makanan dan minuman khas daerah seperti olahan masakan, camilan, minuman, dan oleholeh khas daerah yang biasa terdapat dalam kawasan obyek wisata. Peran perempuan dalam fasilitas di kawasan wisata Pantai Karang Jahe cukup bervariasi, mulai dari pedagang makanan dan minuman, pedagang pakaian oleholeh Pantai Karang Jahe, pedagang olahan hasil laut, pedagang kerajinan tangan atau souvenir, dan pemilik homestay.

c. Peran Perempuan dalam Aksesbilitasi

Dalam hal ini peran perempuan dapat berupa memberikan konsumsi makanan secara bergantian untuk para petugas penertiban jalan atau 
pembangunan akses jalan ke daerah wisata. Peran perempuan dalam aksesbilitas di kawasan wisata Pantai Karang Jahe ditunjukan dengan adanya petugas keamanan atau satpam perempuan yang berjumlah 2 orang. Satpam tersebut bertugas menjaga di loket masuk menuju ke wisata Pantai Karang Jahe, satpam perempuan ini sendiri memiliki tugas untuk memberikan pertolongan dan membantu ketika ada kecelakaan di sekitar pantai, apabila terdapat korban perempuan.

\section{d. Peran Perempuan dalam Tourism Organization}

Dalam pengelolaan wisata Pantai Karang Jahe sudah sedikit banyak melibatkan peran perempuan di dalamnya dengan mempekerjakan satpam perempuan, penjaga loket, dan petugas kebersihan. Namun dalam kepengurusan wisata Pantai Karang Jahe peran perempuan di dalamnya masih di rasa kurang karena hanya ada 1 perempuan yang terlibat dalam struktur organisasi kepungurusan pengelolaan wisata Pantai Karang Jahe.

Dalam struktur organisasi kepungurusan masih di dominasi oleh laki-laki. Namun peran perempuan disini tetap dimanfaatkan, meskipun perbandingannya sangat sedikit dibandingkan dengan pengurus laki-laki. Hal tersebut dikarenakan mindset yang dianut oleh warga Desa Punjulharjo, bahwa perempuan masih dianggap sebagai pengikut bagi kaum laki-laki. Disisi lain rata-rata tingkat pendidikan yang dimiliki oleh para penduduk perempuan di Desa Punjulharjo masih terbilang kurang, kebanyakan hanya tamat SMA saja. Pengelola wisata Pantai Karang Jahe sangat memaksimalkan promosi melalui media online khususnya media sosial seperti facebook, twitter, intagram, youtube, dan whatsapp (WA) sangat efektif untuk menarik minat pengunjung berwisata ke Pantai Karang Jahe.

3. Faktor-Faktor yang Mempengaruhi Peran Perempuan Dalam Pengembangan Pariwisata di Daerah Pesisir Kabupaten Rembang

a. Meningkatkan Perekonomian

Keberadaan wisata Pantai Karang Jahe ini dapat membantu meningkatkan perekonomian warga masyarakat Desa Punjulharjo. Hal tersebut sesuai dengan misi dari obyek wisata Pantai Karang Jahe yang diharapkan mampu meningkatkan kesejahteraan masyarakat lokal melalui kehidupan ekonomi dan meningkatkan pemberdayaan masyarakat desa.

b. Kurangnya Koordinasi

Kurangnya koordinasi dapat mengganggu jalannya sebuah kegiatan dalam masyarakat. Dalam hal ini pengembangan pariwisata berbasis pemberdayaan masyarakat, koordinasi antar pelaku wisata baik pengelola, pelaku usaha, pengunjung, maupun warga sekitar kawasan wisata sangat penting. Namun jika terjadi miss communication, maka akan terjadi kesalah pahaman yang bisa merugikan beberapa pihak. Hubungan antara pedagang dengan pengelola didapatkan memiliki hubungan yang kurang baik. Hal itu dijelaskan bahwa dari pihak pengelola kurang merespon komplain-komplain yang diajukan oleh pedagang di kawasan Pantai Karang Jahe. bahwa pemilihan homestay di sekitar obyek wisata Pantai Karang Jahe ini tidak ada sosialisai yang mendalam dan pemberitahuan yang pasti dari pihak pemerintah desa kepada pemilik rumah. Pemilik homestay sendiri tidak mengetahui homestay yang seharusnya seperti 
apa, bagaimana karakteristik, dan hal-hal lain yang berhubungan dengan homestay.

c. Munculnya Lokasi Wisata Baru

Adanya obyek wisata Pantai Karang Jahe menjadi akar dari munculnya lokasi wisata baru di Kabupaten Rembang. Dengan berkembangnya wisata Pantai Karang Jahe yang semakin baik, membuat desa-desa lain di Kabupaten Rembang termotivasi untuk ikut mengembangkan potensi wisata yang dimiliki. adanya wisata Pantai Karang Jahe ini menjadi embrio atau motivasi bagi desadesa lain yang ingin mengembangkan potensi desa yang dimiliki untuk dijadikan sebagai tempat wisata yang memiliki daya tarik dan memberikan dampak yang positif bagi warga sekitar lokasi wisata.

d. Promosi

Promosi yang dilakukan oleh pengelola Pantai Karang Jahe melalui media online. Media yang digunakan adalah media sosial seperti Facebook, Twitter, Instagram dan juga WhatsApp yang diharapkan mampu mempromosikan Pantai Karang Jahe secara maksimal. Namun untuk official website Pantai Karang Jahe masih belum bisa dikelola dengan baik, bahkan sudah lama tidak update dikarenakan kurangnya SDM yang bisa mengelola website Pantai Karang Jahe. Jadi untuk sementara promosi dilakukan melalui media sosial. Pengelola merasa bahwa promosi dengan media online yang paling efektif, karena dilihat pada masa sekarang ini banyak masyarakat yang menggunakan media online khususnya media sosial dengan cara mengunggah foto-foto dan video kegiatan pengunjung selama berada di Pantai Karang Jahe. Sehingga, hal tersebut sangat membantu dalam penyebaran informasi seputar kegiatan-kegiatan yang dapat membantu pengembangan wisata Pantai Karang Jahe. Pengelola Pantai Karang Jahe sangat berharap melalui promosi ini pengembangan wisata Pantai Karang Jahe bisa lebih baik lagi.

e. Kurangnya Pengetahuan dan Ketrampilan

Kurangnya pengetahuan dan ketrampilan, menyebabkan peran perempuan dalam pengembangan pariwisata di Desa Punjulharjo kurang maksimal. Kebanyakan ibu-ibu yang mendirikan usaha di kawasan Pantai Karang Jahe bekerja sebagai pedagang yang di dominasi oleh pedagang makanan saja. Ratarata masyarakat Desa Punjulharjo masih memiliki kesadaran yang kurang terhadap pentingnya ilmu pengetahuan dan ketrampilan yang dimiliki, sehingga hanya mengandalkan pengalaman pribadi dan pengalaman dari orang-orang terdekat saja. Padahal, pengetahuan dan pengalaman yang dimiliki oleh masingmasing individu menjadi hal yang cukup penting dalam membantu pengembangan pariwisata Pantai Karang Jahe sendiri.

f. Berdomisili di Desa Punjulharjo

Masyarakat yang tinggal di wilayah Desa Punjulharjo otomatis juga ikut berpartisipasi dalam pengembangan wisata Pantai Karang Jahe. Itu juga menjadi faktor mengapa masyarakat khususnya perempuan mengikuti partisipasi dalam pengembangan wisata Pantai Karang Jahe. Dengan sistem pemberdayaan masyarakat lokal, adanya wisata Pantai Karang Jahe bisa dijadikan peluang bagi warga Desa Punjulharjo untuk membuka usaha. Salah satu syarat mendirikan usaha di kawasan wisata Pantai Karang Jahe sendiri juga harus memiliki KK dan 
KTP penduduk Desa Punjulharjo. Jadi apabila warga ingin mendirikan usaha di kawasan wisata Pantai Karang Jahe, mereka harus berstatus penduduk Desa Punjulharjo yang memiliki KTP dan KK penduduk setempat.

g. Masih Adanya Budaya Nenek Moyang

Peran perempuan dalam pengembangan pariwisata di Desa Punjulharjo sampai saat ini bisa dibilang hanya sebagai ikut-ikutan saja. Dalam hal ini yang dimaksudkan adalah perempuan sebagai peran pembantu atau pengikut saja. Masyarakat Desa Punjulharjo khususnya perempuan masih mempercayai budaya leluhur atau nenek moyang, dimana dalam melakukan kegiatan apapun perempuan hanya sebagai peran pembantu dan hanya mengikuti apa yang harus dikerjakan bagi perempuan.

h. Masih Menganut Sistem Patriarki

Sistem patriarki adalah sistem sosial yang menempatkan laki-laki sebagai pemegang kekuasaan utama dan mendominasi dalam peran kepemimpinan politik, otoritas moral, hak sosial dan penguasaan properti. Dalam pengembangan pariwisata di Desa Punjulharjo pada obyek wisata Pantai Karangjahe, masih berpegang pada sistem patriarki dimana dalam melakukan berbagai kegiatan masih didominasi oleh laki-laki. Selama ini warga Desa Punjulharjo masih menggunakan sistem patriarki dalam melakukan berbagai kegiatan bermasyarakat, bahkan dalam hal pariwisata sekalipun. Dimana peran perempuan hanya dianggap sebagai peran pembantu saja dan memiliki kedudukan dibawah laki-laki. Dalam sistem keorganisasian, pekerja laki-laki lebih mendominasi daripada perempuan, dalam hal ini seperti perangkat desa, lembaga BUMDes, dan Pengelola Wisata Pantai Karang Jahe. Perempuan lebih cenderung berperan dalam kegiatan seperti PKK Desa, Posyandu, dan Pengajian.

Pada penelitian ini, peneliti menggunakan Teori Fungsionalisme Struktural Talcott Parsons mengenai konsep AGIL. Konsep AGIL merupakan pengembangan teori fungsionalisme struktural yang mengemukakan empat imperatif fungsional yang harus dipenuhi oleh masyarakat, kelompok atau organisasi. Menggunakan definisi ini, Parsons percaya bahwa ada empat imperatif fungsional yang diperlukan atau menjadi ciri seluruh sistem yaitu Adaptation (adaptasi), Goal attainment (pencapaian tujuan), Integration (integrasi) dan Latency (pemeliharaan pola). Agar bertahan hidup maka suatu sistem harus menjalankan keempat fungsi tersebut (Ritzer dan Goodman, 2010).

Dalam adaptasi masyarakat Desa Punjulharjo khususnya perempuan menyesuaikan keadaan yang terjadi pada keberadaan wistaa Pantai Karang Jahe. Sebelum menjadi tempat wisata, lokasi Pantai Karang Jahe sendiri sebelumnya hanya daerah pesisir pantai utara yang digunakan untuk memancing ikan dan pertambakan garam, dimana pada saat itu masyarakat perempuan Desa Punjulharjo hanya membantu suaminya bekerja sebagai petani garam dan beberapa lainnya bekerja sebagai ibu rumah tangga. Setelah adanya pembangunan wisata Pantai Karang Jahe ini, masyarakat perempuan Desa Punjulharjo diminta oleh pengelola wisata berperan dalam pengembangan wisata Pantai Karang Jahe dengan terlibat sebagai pelaku usaha warung-warung dan fasilitas lainnya di kawasan wisata Pantai Karang Jahe. Kemudian pencapaian tujuan, tujuan utama yang dituju oleh pengelola wisata Pantai Karang Jahe ini adalah pemberdayaan masyarakat, dimana dalam pengembangan pariwisata Pantai Karang Jahe, pengelola melibatkan seluruh masyarakat Desa Punjulharjo untuk berpartisipasi terkhusus masyarakat perempuan yang berperan dengan berdagang menyediakan kebutuhan pengunjung di sepanjang kawasan wisata. Dalam integrasi, 
masyarakat Desa Punjulharjo khususnya perempuan harus bisa beradaptasi dengan keadaan lingkungan mereka yaitu baik dari sebelum adanya pembangunan wisata Pantai Karang Jahe, maupun setelah keberadaan wisata Pantai Karang Jahe. Wisata Pantai Karang Jahe memiliki tujuan yaitu pemberdayaan masyarakat yang melibatkan partisipasi masyarakat Desa Punjulharjo dalam membantu pengembangan pariwisata. Dengan adanya struktur pengelola wisata Pantai Karang Jahe, dapat dijadikan sebagai wadah bagi para anggota komponen pariwisata seperti pedagang, pemilik homestay, penyewaan wahana, dan lainlain, untuk bertukar informasi terkait kegiatan-kegiatan seputar pariwisata, seperti kegiatan pelatihan, sosialiasi atau penyuluhan-penyuluhan baik dari pihak pengelola wisata Pantai Karang Jahe maupun dari pihak-pihak terkait seperti Dinas Kebudayaan dan Pariwisata. Dan pemeliharaan pola disini, masyarakat Desa Punjulharjo harus bisa mempertahankan, memperbaiki dan membaharui motivasi-motivasi dari tiap individu. Selain itu, pola-pola budaya yang diciptakan melalui pengembangan pariwisata seperti dari awal adanya wisata Pantai Karang Jahe sampai sekarang dalam menjaga lokasi wisata dengan memberikan himbauan-himbauan yang harus ditaati oleh seluruh pelaku wisata baik dari pihak pengelola, pelaku usaha, dan pengunjung agar di kawasan lingkungan wisata Pantai Karang Jahe tetap terjaga dengan baik.

\section{PENUTUP}

Hasil penelitian menunjukkan bahwa dinamika peran perempuan dalam pengembangan pariwisata di daerah pesisir Pantai Karang Jahe Desa Punjulharjo Kabupaten Rembang sangat berperan dalam atraksi dan penyediaan fasilitas di kawasan wisata Pantai Karang Jahe. Hal tersebut dibuktikan dari keterlibatan peran perempuan dalam kegiatan pelatihan-pelatihan yang diadakan oleh pihak-pihak terkait dan menyediaakan fasilitas wisata dengan membuka kegiatan usaha seperti berdagang di kawasan wisata untuk menyediakan kebutuhan-kebutuhan pengunjung. Akan tetapi dalam aksesbilitasi dan tourism organization, peran perempuan dirasa masih kurang karena hanya sedikit yang terlibat. Hal tersebut dibuktikan dari keterlibatan peran perempuan yang menjadi petugas keamanan wisata berjumlah 2 orang dan pengelola wisata Pantai Karang Jahe yang hanya memiliki 1 orang pengurus perempuan dan 2 anggota pengelola yang bertugas di pintu loket karcis. Faktor yang mempengaruhi peran perempuan dalam pengembangan pariwisata Pantai Karang Jahe ini berupa : kurangnya koordinasi, kurangnya pengetahuan dan ketrampilan, masih menganut sistem patriarki dan masih adanya budaya nenek moyang yang dianut.

Dinamika Peran perempuan dalam pengembangan pariwisata Pantai Karang Jahe disini dapat diketahui bahwa perempuan mendapatkan pengaruh berupa pelatihan ataupun penyuluhan yang memotivasi untuk menambah pengetahuan dan ketrampilan yang dimiliki. Hal tersebut terjadi karena program-program pelatihan atau penyuluhan tersebut merupakan program yang dicanangkan oleh pemerintah, maka dari itu, peran dan partisipasi masyarakat lokal khususnya perempuan juga sangat diperlukan dalam mensukseskan program pembangunan ini.

Dari penelitian dinamika peran perempuan dalam pengembangan pariwisata di daerah pesisir Pantai Karang Jahe ini peneliti mengharapkan adanya perbaikan untuk kedepannya agar penelitian ini dapat menjadi lebih baik lagi. Berikut beberapa saran yang dapat peneliti berikan :

1. Membangun komunikasi yang baik dengan antar pelaku wisata, agar tidak terjadi konflik dan Pemerintah Desa lebih memberikan informasi yang lebih jelas agar tidak terjadi kesalah pahaman baik antara masyarakat desa. 
2. Meningkatkan kualitas SDM dengan memberikan pelatihan-pelatihan dan penyuluhanpenyuluhan yang dapat menunjang kegiatan pariwisata dan menekankan Sapta Pesona di lingkungan Pantai Karang Jahe.

Lebih banyak melibatkan peran perempuan baik dalam segi kelembagaan maupun kegiatan kepariwisataan, karena dengan adanya peran perempuan maka sistem sosial masyarakat menjadi lebih seimbang.

\section{DAFTAR PUSTAKA}

Ritzer, George dan G. J. Goodman. 2010. Teori Sosiologi Modern. Jakarta: Prenada Media Group.

Sugiyono. 2008. Metode Penelitian Kuantitatif, Kualitatif dan R\&D. Bandung: Alfabeta.

Haryono, Edi dan Nugraheni, Irma Lusi. 2018. Geografi Pesisir dan Kelautan. Yogyakarta : Graha Ilmu.

Undang Undang No.10/2009 tentang kepariwisataan

Redaksi. 2019. Ini Perkembangan Pariwisata Rembang 2018. Rembang. https://rembangkab.go.id/berita/ini-perkembangan-pariwisata-rembang-2018/ diakses pada tanggal 12 November 2019.

2012.

World

Tourism

Organization.

Kemenlu

https://kemlu.go.id/portal/id/read/135/halaman_list_lainnya/world-tourism-organization-unwto dikakses pada tanggal 28 Oktober 2019. 